\title{
Testing the existence of integration; Kuwait and Jordan financial markets
}

\author{
Mohamad H. Atyeh, Wael Al-Rashed \\ College of Business Administration, Kuwait University, Kuwait \\ Email address: \\ modhayel@gmail.com (M. H. Atyeh)
}

To cite this article:

Mohamad H. Atyeh, Wael Al-Rashed. Testing the Existence of Integration; Kuwait and Jordan Financial Markets. International Journal of Economics, Finance and Management Sciences. Vol. 1, No. 2, 2013, pp. 89-94. doi: 10.11648/j.ijefm.20130102.14

\begin{abstract}
The objective of this research is to examine the Arab financial markets integration mainly through its stock markets concentrating on specific countries namely, Kuwait and Jordan. There are several methods have been used to examine the existence of integration. However, the Johansen approach to integration is considered a more reliable method than other conventional integration approaches and is applicable irrespective of the order of integration of the time series. Unlike most of the conventional integration procedures, which are valid for large sample size, Johansen approach is more robust and performs well for large sample sizes. The results show that the null hypothesis of no integration cannot be accepted. This suggests the existence of a long-run relationship between Kuwait and Jordan.
\end{abstract}

Keywords: Financial Markets Integration, Johansen Approach, Law of One Price (LOOP), Capital Asset Pricing Model (CAPM), Market Capitalization

\section{Introduction}

In most developing countries, financial markets have grown rapidly during the last two decades due to several reasons such as the information technology revolution, deregulation and globalization. Integration among the countries has grown during this period all over the world. This is mainly due the direct relationship with the economy, given the important role of the financial markets in the real economic activities.

To attain this objective, the paper examines the existence of financial integration concentrating on two Arab countries, namely, Kuwait and Jordan. The study points out a general outlook on these two financial markets and then it uses a recent econometric technique called, the Johansen approach, to examine the existence of cointegration.

This research project covers indices for the period from June 2001 to March 2010. Kuwaiti market index information was available since March 2001, while the Jordanian market index information was available since January 2000. Therefore, to conduct the study starting from a common date, we started from the monthly index of June 2001 and unified the data of both markets to end up with the monthly index and 106 observations for each.

The research results could be useful for at least the following three main groups of users, namely investors in
Kuwait stock exchange and Jordan stock exchange, Arab financial markets integration researchers, Investment policy makers at the Ministry of Commerce in both Kuwait and Jordan.

\section{Arab Financial Markets Overview}

The majority of Arab countries since the late 1980's became aware of the financial market and private sector importance in developing their economies and achieving the integration. It is worth mentioning that these countries have shown an appreciated commitment and interest, the thing that directly affected the development of their economic structure which led to increasing the number of Arab active financial markets. Starting from only four countries (Lebanon, Kuwait, Jordan and Egypt) during the 1970's until reaching fifteen Arab stock markets in 2010. As per ESCWA (2003), regulations and laws of financial markets are based on the same concerns and issues including the institutional structure, management membership, requirements of listing, financial disclosure, pricing procedures and trading.

This section provides a historical overview of Arab financial markets. Noting that the Arab stock market capitalization jumped from USD 872 billion in the year 2006 until it reached USD 982 billion in year 2010. Total value traded went down from USD 1594 billion in 2006 to USD 333 
billion in year 2010. Shares traded in Arab financial markets have started in year 2006 with between 153 billion shares and ended up with 194 billion traded shares in 2010. Table 1 provides a summary of the total performance of Arab financial markets which includes: KSA, UAE, Egypt, Jordan, Kuwait, Oman, Qatar, Bahrain, Iraq, Morocco, Tunisia, and Lebanon.

Table 1. Arab Financial Markets Main Indicators

\begin{tabular}{llllll}
\hline $\begin{array}{l}\text { Arab Main } \\
\text { Indicators }\end{array}$ & $\mathbf{2 0 0 6}$ & $\mathbf{2 0 0 7}$ & $\mathbf{2 0 0 8}$ & $\mathbf{2 0 0 9}$ & $\mathbf{2 0 1 0}$ \\
\hline $\begin{array}{l}\text { Market Cap } \\
\text { (USD Billion) }\end{array}$ & 872.437 & $1,330.40$ & 805.562 & 887.087 & 982.996 \\
& & & & & \\
Value Traded & 1594.15 & 1005.03 & 892.00 & 567.872 & 333.349 \\
(USD Billion) & & & & & \\
Shares Traded & 153.884 & 281.038 & 280.373 & 350.816 & 194.009 \\
(Billion) & & & & & \\
\hline
\end{tabular}

Source: Arab Monetary Fund

\subsection{Kuwait Financial Market}

In 1962, Kuwait issued the first law that authorizes a Kuwaiti securities market and in 1977 the Kuwait stock exchange (KSE) was opened. During the first Gulf war, KSE operations was suspended and returned back to its operations in 1992. Kuwait has opened the way for foreign investment in year 2000 when the KSE approved the allowance of foreign investors to participate and contribute in the Kuwaiti companies.

The Kuwait financial market is one of the region's oldest sock markets, including 228 companies (214 Kuwaiti companies, 13 foreign companies, and 1 investment fund as of 2010 year end). The largest part is represented by 26 percent operating in the services sector. The rest of companies are involved in different economic activities including banking, financial services, insurance, industrial and food. The main indicators of Kuwait financial market performance are presented in table 2 .

Table 2. Summary of Kuwait Main Indicators

\begin{tabular}{llllll}
\hline $\begin{array}{l}\text { Kuwait Main } \\
\text { Indicators }\end{array}$ & $\mathbf{2 0 0 6}$ & $\mathbf{2 0 0 7}$ & $\mathbf{2 0 0 8}$ & $\mathbf{2 0 0 9}$ & $\mathbf{2 0 1 0}$ \\
\hline $\begin{array}{l}\text { Market Cap } \\
\text { (USD Billion) }\end{array}$ & 141.923 & 193.513 & 113.527 & 104.226 & 123.692 \\
$\begin{array}{l}\text { Value Traded } \\
\text { (USD Billion) }\end{array}$ & 55.714 & 120.659 & 116.023 & 74.162 & 41.094 \\
$\begin{array}{l}\text { Shares Traded } \\
\text { (Billion) }\end{array}$ & 35.520 & 66.207 & 75.820 & 104.541 & 71.301 \\
\hline
\end{tabular}

Source: Arab Monetary Fund
By the end of year 2006, the total market capitalization was equivalent to USD 141 billion. This figure jumped to USD 193 billion in 2007, the second highest figure among the Arab countries after Saudi Arabia. The Kuwaiti market capitalization decreased in year 2010 to USD 123 billion.

The traded value increased from USD 55 billion to USD 120 billion over the period 2006-2007. This figure has reached its maximum in year 2007 and went down again to USD 41 billion in year 2010 .

Shares traded have reached its maximum stage in year 2009 at 104 billion shares after it was 35 billion shares in 2006. The Kuwaiti market traded shares dropped again until it reached 71 billion shares in 2010 .

\subsection{Jordanian Financial Market}

The public trading in shares is there in Jordan since the 1930's which is the decade of establishing the first shareholding company in Jordan. In 1976, Jordan has officially established Amman Financial Market (AFM) which was converted in 1999 to Amman Stock Exchange (ASE) as a private non-profit institution that is responsible of operating the Jordan securities market.

Amman Stock Exchange consists of 277 companies operate in different market sectors. Financial services companies represent the majority of the market at a stake of $42 \%$. The industrial sector comes second after the financial services to be followed by the services sector that includes activities such as tobacco, glass, construction, electrical and mining. Table 3 presents the main indicators of Jordan financial market as follows:

Table 3. Arab Financial Market Main Indicators

\begin{tabular}{|c|c|c|c|c|c|}
\hline Jordan Main Indicators & 2006 & 2007 & 2008 & 2009 & 2010 \\
\hline $\begin{array}{l}\text { Market Cap } \\
\text { ( USD Billion) }\end{array}$ & 29.785 & 41.298 & 35.984 & 31.985 & 30.037 \\
\hline $\begin{array}{l}\text { Value Traded } \\
\text { (USD Billion) }\end{array}$ & 19.544 & 17.109 & 27.079 & 13.616 & 9.049 \\
\hline Shares Traded (Billion) & 3.990 & 4.387 & 5.112 & 5.991 & 6.619 \\
\hline
\end{tabular}

Source: Arab Monetary Fund

Market capitalization increased from USD 29 billion in 2006 to USD 41 billion in 2007 and went down to become USD 30 billion in 2010 noting that the maximum market capitalization figure was achieved in 2007 at USD 41 Billion.

In 2006, the value of traded shares was USD 19 billion; more than double the value of USD 9 billion in 2010. In year 2008 the trading value has reached its maximum at USD 27 billion.

The number of traded shares in 2006 was around 4 billion shares. This number has kept increasing until reaching its highest record in 2010 with more than 6 billion shares.

\section{Literature Review}


There are many research were conducted regarding the financial markets integration. Many indicators were developed to examine the existence of integration but the "Law of one price" or what is known by LOOP is the common factor of all these indicators and measures. In general, financial integration refers to a condition where there are no barriers such as transaction costs, legal restrictions, taxes and tariffs stands against the mobility and trade in foreign assets or the equity flows of portfolios.

Stulz (1981) defined the integration of financial markets as "if assets with perfectly correlated returns have the same price, regardless of the location in which they trade". A fully integrated financial market is defined as a situation where investors earn the same risk adjusted expected return on similar financial instruments in different public markets, Philippe and Schwartz (1986) which means the lack of arbitrage profit achievement. In other words, if the risk of an identical financial instrument is traded on the same price in different markets, then it will be an indication of integration between these markets. However, a financial market is considered to be more integrated, if there are stronger domestic returns depend on shocks of world market, which means that the internal market is interacting with the world market. This definition underlines not only the openness of financial markets but also measures directly the extent to which shocks are transferred across financial markets. The transfer of a shock requires both the removal of barriers and the capital flows across markets in order to take advantage of market opportunities, Fratzscher (2002). It is believed that, in case of a more fully integrated financial market, the country's economy and the subject market will not be separated from any external influence.

Choudhry et al. (2007) and Masih and Masih (2002) mentioned that financial markets development improves the degree of integration among these markets. Moreover, financial integration among markets has gained considerable attention of both the finance specialists and policy makers.

To summarize, we will refer to Narayan et al (2004) and Von Furstenberg and Jeon (1989) conclusions. The previous studies say that, if two securities have identical cash flows, they should have the same price. In other words, all assets with similar identifications and same risk characteristics should generate the same return in the different markets ignoring the location or any other factors.

Portfolio diversification and management are considered as important implications of the existence of a long run relationship between financial markets. Kearny and Lucey (2004) mentioned that when there is no integration, investors may try to reduce the risk through diversifying their portfolio among financial markets. Therefore, there is a contrary relationship between the benefits generated out of diversifying the portfolio and the level of financial markets integration.

There are two common methods to measure or examine the financial markets integration: the first method is the ICAPM or the international capital asset pricing model, and the second method is through using the approaches of cointegration.

The ICAPM assumes that the financial markets are integrated. ICAPM comes opposite to the CAPM which assumes that financial markets are segmented. Moreover, the ICAPM assumes that financial markets are integrated when two securities with same risk characteristics in two different markets have the same price levels. Several studies were conducted using the ICAPM as a measurement of integration such as Solink (1974), Stutz (1981), Alder and Dumas (1983), Philippe and Schwartz (1986). Buckberg (1995). Buckberg in his study used the data of twenty emerging financial makets for the period between 1977 and 1991 on a monthly basis. The results of the previous study indicated that eighteen countries out of the twenty are integrated mainly due to the cash flow coming from the industrial countries during 1980's.

The most popular methods used to test the extent of integration between financial markets are the cointegration approaches.

Azman and other researchers in 2002 mentioned that, one of the stock prices habits is that over a long period the stock prices tend to move together and follow a common upward trend. In other words, common trends are expected to be achieved out of these indices if financial markets are integrated. This means that, the co-movements between securities prices represent an indication for the existence of integration. Moreover this co-movement or common trend implies that one market will help in predicting the returns of the other, due to the existence of a valid error correction representation.

Kasa in 1992 was one of the earliest researchers to measure the existence of financial integration using cointegration approach. In his research, Kasa finds that five (list them) industrial countries are correlated perfectly. These countries are USA, Canada, Germany, England and Japan. The cointegration approach of Johansen-Juselius was used by Ali Darrat et al. (2000). The previous study was explored to examine the integration between Morocco, Jordan and Egypt and to what extent they are linked among themselves and with the international financial markets. The research concluded that most Middle East and North Africa (MENA) countries are segmented internationally and integrated regionally. The financial markets integration in the MENA region was examined also by Neaime (2002) using the Engle-Granger efficient maximum likelihood test to examine the existence of the long-term relationship among the MENA markets themselves and between the MENA markets and the world markets represented by the US, UK and French markets. The study indicated a solid integration between MENA countries and developed markets and a weak integration among MENA markets. A research conducted by Marashdeh (2005) to examine the extent of financial integration in the MENA region, using the ARDL approach. Marashdeh adopted the ARDL approach to examine the long-run equilibrium relationship among stock price indices in the MENA region stock markets. Long run equilibrium relationships were found in MENA region 
markets. The empirical findings of this study indicated that the stock markets in the MENA region are found to be integrated with each other.

Febrian and Choudhry et al. (2007), Narayan et al. (2004), Herwany (2007) and Yang et al. (2003) use different cointegration approaches to measure financial market integration among several markets in Asia. Different results were reported regarding the integration of these financial markets.

There are not many of research studies conducted to examine the extent of integration among Gulf Corporation Council (GCC) financial markets. Abraham et al. (2001) applied the examination on Kuwait, Saudi Arabia and Bahrain and reached a low correlation between these three financial markets. A long-term equilibrium relationship between three GCC markets founded by Hassan (2003) namely, Bahrain, Kuwait and Oman.

Johansen-Juselius (1990) method used by Al-khazali et al. (2006) to examine the intra regional integration of the GCC stock markets, namely, Kuwait, Bahrain, Saudi Arabia, and Oman. The research finds a common stochastic trend over the long run among these countries. Other research conducted by Alkulaib et al. (2009) argues that the GCC region has more interaction and linkage than the MENA region due to the similar economic nature of these countries.

\section{Methodology}

This paper uses the Johansen approach to examine the existence of cointegration between Kuwait and Jordan financial markets. The Johansen approach to cointegration is a method tests the existence of integration of several time series. Moreover, this method permits more than one cointegrating relationship and it more applicable and reliable method than other conventional cointegration approaches. In addition, it is applicable irrespective of the order of integration of the time series, more robust and performs well for large sample sizes. The existence of an error-correction term among a number of cointegrated variables implies that changes in the dependent variable are a function of both the level of disequilibrium in the cointegration relationship (represented by the ECM) and the changes in other explanatory variables.

This tells us that any deviation from the long-run equilibrium will feed back to the changes in the dependent variable in order to force the movement towards the long-run equilibrium (Masih and Masih, 2002, p. 69).

To analyze the relationship among the two markets, individual model for each market is employed based on the following general model (Linear Regression Model):

$$
\mathrm{y}=\alpha+\beta_{i} X_{i}+u
$$

where,

$\mathrm{y}$ - Stock market as dependent variable

$X_{i}$ - Stock market as independent variable

$\alpha$ is the Intercept

$u$ is constant
In the previous model, Kuwait market is the dependent variable while Jordan is an independent variable. In the second model, Jordan becomes dependent variable and Kuwait becomes an independent variable.

In the above model, the null hypothesis of no cointegration for each of the dependent variables is: $\left(H_{0}: \gamma_{1}=\gamma_{2}=\right.$ $0)$ and it is tested against the alternative hypothesis $\left(H_{A}: \gamma_{1} \neq \gamma_{2} \neq 0\right)$. These hypotheses are examined using the standard F-statistics of Pesaran and Pesaran (1997). Asymptotic critical values are provided by Pesaran and Pesaran (1997) and Pesaran et al (2001). If the computed F-statistics is greater than the F distribution critical value, then we reject the null hypothesis of no cointegration and conclude that there exists steady state equilibrium between the variables. If the computed F-statistics is less than the F distribution critical value, then the null hypothesis of no cointegration cannot be rejected.

\section{Data and Descriptive Statistics}

This study uses the monthly stock price indices for a period ranging from June 2001 to March 2010. These indices are for two Arab markets, namely, Kuwait and Jordan. Kuwaiti market index information was available since June 2001, while the Jordanian market index information was available since January 2000. Therefore, to conduct the study starting from a common date, we started from the monthly index of March 2001 and unified the data of both markets to end up with the monthly index and 106 observations for each.

Table 4. Group Descriptive Statistics for the Sample Markets

\begin{tabular}{lll}
\hline Variable & Kuwait & Jordan \\
\hline Mean & 7564.80 & 2459.50 \\
Maximum & 7878.20 & 2534.70 \\
Minimum & 7025.30 & 2374.80 \\
Std. Dev. & 271.40 & 58.90 \\
Skewness & 0.12 & 0.04 \\
Kurtosis & 1.98 & 1.81 \\
Jarque-Bera & 4.89 & 6.30 \\
Probability & 0.09 & 0.04 \\
Observations & 106 & 106 \\
\hline
\end{tabular}

The Kuwaiti financial market or Kuwait Stock Exchange (KSE) consists of six main industries and they are: banking, investment, insurance, real estate, food and industrial sector. The foreign companies are given a separate sector called non Kuwaiti companies to end up with seven sectors.

The Jordanian financial market or Amman Stock Exchange (ASE) is classified into three main sectors. First, the financial sector which consists of four subsectors, banks, insurance, financial services and real estate sector. The services sector is the second and it is divided into eight subsectors and they are; health care, Education, hotels and 
tourism, transportation, technology and communication, media utilities and commercial services. Finally, the industrial sector which consists of 11 subsectors as follows: pharmaceutical and medical industries, chemical, paper and cartoon, printing and packaging, food and beverages, tobacco, mining and extraction, engineering and construction, electric, textiles, leather and clothing, glass and ceramic industry.

The stock price indices of Kuwait and Jordan show that the stock prices in Kuwait constantly increased until the first quarter of 2008 and then sharply declined.

Jordan market saw a decline in stock prices in 2005. Recovery in these markets started in 2006 reaching another peak in 2008 but declined afterwards.

\section{Results and Discussions}

The results of the bound test reported in table 5 show that when Kuwait financial market is a dependent variable, the calculated F-statistics (2.37) is greater than the F distribution critical value at 5 percent significance level (1.91). Thus, the null hypothesis of no cointegration cannot be accepted. This suggests the existence of a long-run relationship between Kuwait and Jordan. When Jordan is the dependent variable, the calculated F-statistics (6.17) is also higher than the F distribution critical value at 5 percent significance level (1.91). Thus the null hypothesis of no cointegration is rejected here as well.

Table 5. Test Results

\begin{tabular}{ll}
\hline Null Hypothesis: & F-Statistic \\
\hline INDEXJO does not Granger Cause INDEXKW & 2.37947 \\
INDEXKW does not Granger Cause INDEXJO & 6.17350 \\
\hline
\end{tabular}

\section{Summary and Conclusion}

We have discussed the Arab financial markets in general and went through two relevant stock markets. Moreover we have analyzed the past five year's performance and trend of these markets. In addition, we have concentrated our analysis on two Arab countries namely Kuwait and Jordan.

We have analyzed the historical trend and performance of these two specific markets and investigated the long-run relationship and linkages of these two Arab financial markets.

The test results show that the two markets seem to be integrated between themselves. According to the results, both markets are moving together in the same direction. In these markets, potential gains from portfolio diversification should not be achieved since systematic risk cannot be diversified and arbitrage opportunities among them are limited in the long-run as the law of one price (LOOP) is possible to take place.

\section{Implications of the Study}

The empirical findings mentioned above have several important implications on achieving profits through portfolio diversification between the different markets. The existence of cointegration among these two markets implies the existence of the law of one price (LOOP). This means that the potential of investors in these markets for obtaining abnormal profits through portfolio diversification is limited in the long-run. The reason for this is that as the markets are cointegrated, abnormal profits will be arbitraged away in the long-run. However, despite no arbitrage opportunities in the long-run, investors can still achieve arbitrage profits through portfolio diversification in the short-run.

\section{References}

[1] Abraham, A., Seyyed, F. and Al-Elg, A. (2001),"Analysis of diversification benefits of investing in the emerging Gulf equity markets", Managerial Finance, Vol. 27, pp. 47-57.

[2] Adler, M. and Dumas, B. (1983).“'International portfolio selection and corporate finance: a synthesis", Journal of finance, 46, pp. 925-984.

[3] Al-Khazali O., Darrat A. and Mohsen S. (2006)."Intra-regional integration of the GCC stock markets: the role of market liberalization", Applied Financial Economics, Vol. 16, issue 17, pp. $1265-1272$.

[4] Alkulaib Y., Najad, M. and Mashayekh, A. (2009)."Dynamic linkages among equity markets in the Middle East and North Africa Countries", Journal of Multinational Financial Management, Vol. 19, pp. 43-53.

[5] Assaf, A. (2003). "Transmission of Stock Price Movements: The Case of GCC Stock Markets", Review of Middle East Economics and Finance: Vol. 1, No. 2.

[6] Azman, S. at. el. (2002). "Financial integration and the ASEAN-5 equity markets", Applied Economics, 34, pp.2283-2289.

[7] Buckberg, E. (1995). "Emerging stock markets and international asset pricing", The World Bank Economic Review, 9 , pp. 51-74.

[8] Choudhry, T. Lin, L. and Peng, K. (2007). "Common stochastic trends among Far East stock prices: Effects of the Asian financial crisis", International Review of Financial Analysis, 16, 242-261.

[9] Darrat, F., Elkhal, K. and Hakim R. (2000). "On the integration of emerging stock markets in the Middle East", Journal of Economic Development, 25, pp. 119-129.

[10] Enders, W. (2004), "Applied Econometrics times series", second edition, John Wiley \& Sons.

[11] Elaine, B. (1995), "Emerging stock markets and international asset pricing", The World Bank Economic Review, 9, pp. $51-74$.

[12] Engle, F. and. Granger, C. (1987).“Co-integration and error correction representation, estimation, and testing, Econometrica, 55, pp. 251-276.

[13] Febrian, E. and Herwany, A. (2007). "Co-integration and Causality among Jakarta Stock Exchange, Singapore Stock 
Exchange, and Kuala Lumpur Stock Exchange", MPRA Paper, No. 9637.

[14] Fratzscher, M. (2002). "Financial market integration in Europe: on the effect of EMU on stock markets", International Journal of Finance and Economic, 7, pp. 165-193.

[15] Hassan, M. (2003)."Financial Integration of stock markets in the Gulf: A multivariates cointegration analysis", International Journal of Business, Vol. 8, No. 3.

[16] Johansen, S. (1988). "Statistical analysis of cointegration vectors", Journal of Economic Dynamic and Control, 12, pp. 231-254.

[17] Johansen, S. and Juselius, K. (1990), "Maximum likelihood estimation and inference on cointegration-with application to the demand for money", Oxford Bulletin of Economics and Statistics", 52, pp. 169-210.

[18] Kasa, K. (1992). "Common stochastic trends in international stock markets", Journal of Monetary Economics, 29, pp. 95-124.

[19] Kearney, C. and Lucey, B.M. (2004). "International Equity Market Integration: TheoryEvidence and Implications', International Review of Financial Analysis, vol.13, no. 5, pp. 571-583.

[20] Masih, R. and Mansur M. (2002)."Long and short term dynamic causal transmission amongst international stock markets", Journal of International Money and Finance, 20, pp. 563-587.

[21] Muhammad, N. ( 2007)."Short-term and long-term stock price linkages among the GCC stock markets and with the U.S. stock market", Working Paper Series of the University of Wollongong in Dubai, No. 60, UAE.
[22] Marashdeh, H. (2005). "Financial Integration of the MENA Emerging Stock Markets", University of Wollongong, Australia.

[23] Neaime, S. (2002). "Liberalization and financial integration of MENA stock markets", a paper prepared at the ERF's 9th annual conference on "Finance and Banking", United Arab Emirates.

[24] Pesaran, H., Shin and Smith, (1996). "Testing for the existence of a long-run relationship", DAE Working Papers, No. 9622, Department of Applied Economics, University of Cambridge, UK.

[25] Pesaran, M. and Pesaran, B. (1997). Microfit 4.0, Oxford University Press, Oxford.

[26] Simpson, J. and Evans, J. (2004). "Interdependence in Gulf Cooperating Stock Markets". Working Paper Series of the University of Wollongong in Dubai, No. 4.

[27] Philippe, J. and Schwartz, E. (1986). "Integration vs. segmentation in the Canadian Stock Market" Journal of Finance, 41, pp. 603-616.

[28] Solink, B. (1974). "An equilibrium model of the international capital market", Journal of Economic Theory, 8, pp. 500-524.

[29] Stulz, R. (1981). "A model of international assets pricing", Journal of Financial Economics, 9, pp. 383-406.

[30] Von Furstenberg, M. and Jeon, N. (1989). "International stock price movements: links and messages", Brookings Papers on Economic Activity, 1, pp. 125-179.

[31] Yang J., Kolar, W. and Insik, M. (2003). "Stock market integration and financial crisis: the case of Asia", Applied Financial Economics, 13, pp. 477-486. 